\title{
Analysis of the economic feasibility and reduction of a building's energy consumption and emissions when integrating hybrid solar thermal/PV/micro-CHP systems
}

\author{
Laura Romero Rodríguez ${ }^{a,}{ }^{*}$, José Manuel Salmerón Lissén ${ }^{a}$, José Sánchez \\ Ramos $^{b}$, Enrique Ángel Rodríguez Jara ${ }^{b}$, Servando Álvarez Domínguez ${ }^{a}$
}

a Grupo de Termotecnia, Escuela Superior de Ingenieros, Universidad de Sevilla. Camino de los Descubrimientos S/N, 41092 Sevilla, Spain.

$b$

Escuela Superior de Ingeniería, Departamento de Máquinas y Motores Térmicos, Universidad de Cádiz. C/Chile 1, 11002 Cádiz, Spain.

* Corresponding author: Laura Romero Rodríguez. E-mail: $\underline{\text { Irr@us.es }}$

\section{ABSTRACT}

The aim of this paper is to assess the performance of several designs of hybrid systems composed of solar thermal collectors, photovoltaic panels and natural gas Internal Combustion Engines. The software TRNSYS 17 has been used to perform all the calculations and data processing, as well as an optimisation of the tank volumes through an add-in coupled with the GENOPT ${ }^{\circledR}$ software. The study is carried out by analysing the behaviour of the designed systems and the conventional case in five different locations of Spain with diverse climatic characteristics, evaluating the same building in all cases. Regulators, manufacturers and energy service engineers are the most interested in these results.

Two major contributions in this paper are the calculations of primary energy consumption and emissions and the inclusion of a Life Cycle Cost analysis. A table which shows the order of preference regarding those criteria for each considered case study is also included. This was fulfilled in the interest of comparing between the different configurations and climatic zones so as to obtain conclusions on each of them. The study also illustrates a sensibility analysis regarding energy prices. Finally, the exhaustive literature review, the novel electricity consumption profile of the building and the illustration of the influence of the cogeneration engine working hours are also valuable outputs of this paper, developed in order to address the knowledge gap and the ongoing challenges in the field of distributed generation.

\section{Introduction}

\subsection{Background and main achievements}

In the recent years, the concept of energy efficiency has been receiving widespread attention due to the realization that fossil fuel resources required for energy generation are finite and that climate change is linked to carbon emissions. This has encouraged a tremendous amount of studies with different approaches related to the implementation of technologies capable of both producing energy in a more efficient way and diminishing its environmental impact. 
These studies include the use of technologies such as Combined Heat and Power (CHP) production, also known as cogeneration systems, which are able to produce electricity and thermal energy from the same source. They are considered to be crucial to achieve such goals by many international organisms due to their many benefits. For instance, the power production process is more efficient, polluting emissions are diminished, there are fewer losses in the distribution network and the reliability and quality of the supplied energy is increased.

However, an appropriate normative context is essential so as to provide economic feasibility to the projects, thus minimising the risks present within the energy market. Its benefits are recognised by governments all over the world and in the case of Europe supported by the European Parliament through different directives. Despite that and the suitability of a country such as Spain regarding renewable energy implementation, its legislative uncertainty is nowadays quite high due to the government's willingness to enforce a Decree which imposes taxes to installations destined for selfconsumption. This seems to be inconsistent with all the efforts aimed at improving energy efficiency and also dissuades from using new technologies, the most recent ones derived from advances related to electricity storage solutions.

Apart from that, buildings are pointed out as a sector with a considerable potential for more efficient energy production systems. The need to produce energy more efficiently in buildings is one of the reasons for the importance of CHP systems among the great range of different technologies, especially in countries such as Spain where its presence these days is merely anecdotic (just a few practical experiences in hospitals, hotels and dwellings).

The knowledge gap between what works and the widespread adoption of practical implementations is a major preoccupation of researchers and policy makers. There seems to be no immutable formula for a successful implementation of new innovations. Thus, developing strong and reliable evidence on the overall behavior of such innovations is a compulsory task which this paper aims to fulfill as a valuable addition to current approaches.

This paper offers an innovative approach when it comes to providing energy to buildings. It focuses on both the electrical and thermal elements unlike most studies in which the thermal part plays a secondary role, with little regard to its effects on the performance of the system. Many studies have been developed on PV, solar thermal and wind technologies, but relatively few on their integration with cogeneration systems: hybrid systems, where all these technologies are combined with the idea of improving energy efficiency. In this paper, we analyze different configurations of such an installation including natural gas Internal Combustion Engines, PV, and solar thermal energy, unlike previous studies which only refer to stand-alone systems $([6,10-15,17])$, or do not include nor compare all our considered components ([1-38]).

In addition, in contrast to previous publications this study develops an exhaustive analysis of the Life Cycle Costs, emissions and primary energy consumption, and should be regarded as a step towards the goals included within the new concept of "Smart Energy Networks", which aims to integrate all energy sources in order to increase energy efficiency. An added strength of the study is the use of a novel electricity consumption profile of the building, which has been innovatively obtained by combining several institutional projects on energy consumption habits.

Finally, another significant contribution of this paper is the illustration of the influence of the cogeneration engine working hours and its importance so as to improve the economic feasibility of hybrid systems. The results are promising and show very interesting findings about the usefulness of such systems in the near future. On the verge of an energy crisis, the conditions will most probably be conducive to their wide employment in real applications. 


\subsection{Decentralised Generation}

Distributed Generation (DG) systems have many advantages, including very high certainty of supply, high efficiency power generation and high adaptability to changes in demand (both daily and yearly). The DG systems can be compared in its essence and mode of operation to the Internet or to mobile networks [3].

Distributed generation and renewable energy sources worldwide and in Europe [4] have attracted considerable interest and are regarded as essential in view of two political objectives:

-Increasing Europe's energy security by reducing dependence on imported fossil fuels such as oil, natural gas and coal.

-Reducing greenhouse gas emissions, especially carbon dioxide [5] from burning fossil fuels.

\subsection{Micro-CHP}

Micro-CHP is a special type of Distributed Generation systems. Its units are localised power generating stations, producing both heat and electricity at the point of use and can export the excess electricity generated if connected to the national grid. The thermal output is used for hot water and space heating while the AC electricity is used locally in the house or, if demand is sufficiently low, fed onto the local distribution system.

Micro-CHP systems are especially suited to situations where there are simultaneous heat and power demand, as is prevalent in houses in northern European countries. The benefits of micro-CHP units are considered in [6].

Nowadays, one of the main disadvantages of micro-CHP systems is the investment necessary in order to acquire all the equipment, either stand-alone or grid-connected. The costs differ depending on the technology used, and research is essential with a view to gain knowledge to minimise costs and achieve grid parity in the near future.

\subsection{Previous studies on combined use of energy sources in buildings}

Building integration of micro-CHP systems is a challenge, since the thermal and electric loads are small and the diversity high. To properly integrate a micro-CHP system into a residential building a significant number of issues need to be solved, and for that reason many studies have been released on this topic (see [7]).

Furthermore, there are many studies on the application of internal combustion engines in residential buildings from several points of view: environmental, economic feasibility and so on (see [7-9] and the references therein). A very interesting case study of a typical CHP application with emphasis on the operational flexibility is considered in [40]. It also includes a sensitivity analysis on all major economic parameters.

Another interesting paper ([41]) includes an optimisation model for the capacity and dispatch of decentralised $\mathrm{mCHP}$ systems, focusing on a very thorough sensitivity analysis of costs.

\subsection{Hybrid systems}

In the last decades many studies have been performed on PV and wind technologies (to produce electricity) and on solar thermal energy (to produce hot water). For instance, [42] develops a highly recommendable review of papers which examine options for increasing residential PV self-consumption. 
Nevertheless, relatively few studies have been carried out on the integration of these technologies or any of its subgroups with cogeneration systems (hybrid systems). These systems present a new dimension to the time correlation of intermittent renewable energy sources.

Many of these studies refer to stand-alone systems $([6,10-15,17])$. Other studies take into account only some components $([2,9,10,18])$, techno-economic optimization ([13, 19]), cost of energy ([3]), technological optimization $([15,20]$, and the references therein), micro-generation systems for variable electricity prices ([21]), optimization of stand-alone hybrid renewable energy systems([16, 20]), performance analysis of integrated CHP systems for residential applications ([22-23]), comparisons between two generation components in grid-connected and stand-alone power supply systems, evaluation of system performance in building application ([24-27]), and others. One more important issue about hybrid power systems is the cost of the possible solutions on different geographic zones (see $[11,14]$ and the bibliography therein).

In addition, simulation plays an important role in the studies on new technological advances. An example of this kind of study which required simulations is [1]. Among the software mentioned in literature, many papers have based their results in the simulations executed with the software HOMER (see $[11,19,27,25])$, used to design and evaluate technically and financially the technologies for off-grid and on-grid power systems for remote, stand-alone and distributed generation applications.

In our case, the software TRNSYS 17 has been used to carry out all the simulations, one of the reasons being that it allows for the exploration of new technologies far more easily than in less flexible software, in view of the fact that every single parameter can be modified without effort in contrast to the opacity of other tools. Many other studies have been successfully developed in this simulation package. A paper which used TRNSYS for similar simulations is [26].

To determine the operating conditions for a hybrid system is a main issue to obtain high performances in these systems.

- Mago et al ([28]) accomplished analyses and optimization of different CHP operational strategies (by following electrical load, thermal load or hybrid electrical-thermal load) based on several optimization criteria such as energy savings, operational cost reduction or minimum environmental impact.

-The technical and economic uncertainties in the design and operation of micro-CHP systems have been discussed in [29].

\subsection{Fuel cell hybrid systems}

Unlike our current study, an important amount of papers are based on hybrid systems which include fuel cell technology (FC). However, its use has not been taken into account in our case. Likewise, Natural Gas engines are not usually considered for these kinds of studies, although a control strategy for such an engine was developed in [3].

Nevertheless, because of its interest in certain aspects the following studies are worth mentioning:

-Several methods for operating a fuel cell and solar hybrid system through field experiments were examined in [30]. In this paper optimum capacities of photovoltaic (PV), solar collector and FC to minimise primary energy consumption of the system are also studied. A feasibility study appears in [31]. 
-The operation method and the capacity of each piece of equipment in the arrangement of a completely energy independent micro-grid consisted of PV, water electrolysers, protonexchange membrane fuel cells and heat pumps have been investigated in ([32]).

-Dorer et al ([33]) analysed sizing of fuel cell systems in relation to the thermal demand of the building, investigated the impact of hot water storage size and studied predictive energy management/control strategies.

-A combined cooling, heating and power (CCHP) system has been studied in [34]. A methodology for the optimal design of hybrid systems has been shown in [35].

\subsection{Smart grids and Smart Energy Networks}

Researchers should bear in mind the evolution in recent years from the concept of distributed generation and Smart Grids, to that of Smart Energy Networks which do not only integrate electricity but also every energy source available, including also management and communication methods. The proposals suggest to see the system as a unified whole [36]. In this manner, several studies point out that the existing infrastructure and the electricity generation process will have to evolve in order to satisfy the new concept of Smart Energy Networks (SEN) beyond the constraints of distributed generation.

Specially, it can be said that not only renewable energy sources should be considered, but also high efficiency cogeneration systems may be a promising solution in SEN to supply energy in an effective way. Through a great variety from generators to customers in urban areas, these cogeneration systems could also help to integrate renewable technologies on a large scale [37, 38]. This study should be regarded as a step towards these goals.

\section{Method: characteristics of the study}

\subsection{Description of the installation}

As previously highlighted in the literature review, very few investigations have been carried out on hybrid systems that join solar thermal energy devices with a micro-CHP system.

Our study will consist on designing the energy production system (electricity, domestic hot water (DHW), heating and cooling) for a residential block of flats. We have attempted an innovative approach on a micro-CHP hybrid system that combines solar thermal energy, photovoltaics and natural gas internal combustion engines to supply most of the energy for the building. Furthermore, a Life Cycle Cost analysis and emission calculations will be carried out in the last section, as well as a sensitivity analysis of energy costs.

Taking those characteristics into account, our system differs in many aspects from those designed in previous studies. For instance, it is not stand-alone such as [6], [10-15] and [17], although it could be turned into one with certain modifications. However, it considers many aspects which other studies fail to bear in mind, for example using software which allows uncomplicated adjustments in the system in order to make alterations easily in the future. The Life Cycle Costs of different configurations have also been calculated similarly to [13], so as to be able to compare between them and also the conventional case in which we obtain electricity from the grid, and use natural gas for the heating and domestic hot water boilers. Likewise, [43] aims at optimizing the life cycle performance of a hybrid combined cooling heating and power (CCHP) system, following electrical load (FEL) and thermal load (FTL) strategies. Finally, the emissions of the diverse configurations have been calculated in order to compare their performance, in analogy with papers on reduction of emissions such as [1] and [2]. 


\subsection{Building and climate}

The building which is going to be analysed is a six-storey residential block chosen as much representative as possible of the current Spanish architecture. It is an east facing building located between party walls and has $1304 \mathrm{~m}^{2}$ in total. There are 12 building units, 2 in each floor.

The study will be carried out for five different geographical locations of Spain, the reference cities of the climatic zones A3, B4, C2, D3 and E1 (Cádiz, Seville, Barcelona, Madrid and Burgos respectively), where " $A$ " indicates the less severe climate in winter and " $E$ " the most severe; similarly " 1 " indicates the less severe climate in summer and " 4 " the most severe [39]. For each location, weather data such as temperatures, solar radiation and network water temperatures are provided.

\subsection{Building energy needs}

Heating, cooling and DHW demands of the building depend on which climatic zone it is located. Thus, to obtain the values of demand we had to run simulations of the building (located in those five different zones) with the software LIDER [44]. As a result, we obtained the hourly energy demand values of space heating and cooling for each of those cases. DHW demand was calculated through Spanish standards. The summary of the electricity, heating, DHW and cooling annual demands for each climatic zone (in $\mathrm{kWh} / \mathrm{m}^{2}$ ) is the following:

\begin{tabular}{|l|l|l|l|l|}
\hline $\begin{array}{l}\text { Climatic } \\
\text { Zone }\end{array}$ & $\begin{array}{l}\text { Electricity } \\
\text { demand } \\
{\left[\mathrm{kWh} / \mathrm{m}^{2}\right]}\end{array}$ & $\begin{array}{l}\text { Heating } \\
\text { demand } \\
{\left[\mathrm{kWh} / \mathrm{m}^{2}\right]}\end{array}$ & $\begin{array}{l}\text { DHW } \\
\text { demand } \\
{\left[\mathrm{kWh} / \mathrm{m}^{2}\right]}\end{array}$ & $\begin{array}{l}\text { Cooling } \\
\text { demand } \\
{\left[\mathrm{kWh} / \mathrm{m}^{2}\right]}\end{array}$ \\
\hline A3 & 26.16 & 4.93 & 12.87 & 15.33 \\
\hline B4 & 26.16 & 8.46 & 13.66 & 28.26 \\
\hline C2 & 26.16 & 18.85 & 12.84 & 8.22 \\
\hline D3 & 26.16 & 29.87 & 13.15 & 19.57 \\
\hline E1 & 26.16 & 43.03 & 13.85 & 2.15 \\
\hline
\end{tabular}

Table 1: Electricity, heating, DHW and cooling annual demands for each climatic zone in Spain.

On the other hand, we also want to provide the building with the electricity it consumes. However, it is considerably intricate to obtain data of the consumption patterns in residential buildings. After studying the available information, we used the annual data and daily profiles of certain appliances provided by the projects "EURECO" [45], "SPAHOUSEC" [46] and "ENCERTICUS" [47], in order to innovatively create an average profile of the electric consumption of a household for each month of the year. The latter is also based on experimental measurements, and thus was used merely to verify the consistency of the obtained results. 
The following table sums up the contribution of each of those projects:

\begin{tabular}{|c|c|c|c|c|}
\hline Project & $\begin{array}{l}\text { Aggregate } \\
\text { Annual } \\
\text { Output }\end{array}$ & $\begin{array}{l}\text { Monthly } \\
\text { Variations }\end{array}$ & \multicolumn{2}{|c|}{ Daily profiles } \\
\hline \multirow{5}{*}{ EURECO } & \multirow{5}{*}{-} & \multirow{5}{*}{$\mathrm{X}$} & \multirow{5}{*}{$\mathrm{X}$} & Lighting \\
\hline & & & & Clothes-dryer \\
\hline & & & & Freezer \\
\hline & & & & TV \\
\hline & & & & Computer \\
\hline \multirow{6}{*}{ SPAHOUSEC } & \multirow{6}{*}{$\mathrm{X}$} & \multirow{6}{*}{$\mathrm{X}$} & \multirow{6}{*}{$\mathrm{X}$} & Cooking \\
\hline & & & & Clothes-washer \\
\hline & & & & Dishwasher \\
\hline & & & & Standby \\
\hline & & & & Refrigerator \\
\hline & & & & Oven \\
\hline ENCERTICUS & $X$ & - & - & - \\
\hline
\end{tabular}

Table 2: Daily profiles, monthly variation and yearly output provided by several projects on consumption patterns in residential buildings.

As an example, the average electricity consumption profile that we obtained for a single dwelling in Spain is illustrated below:

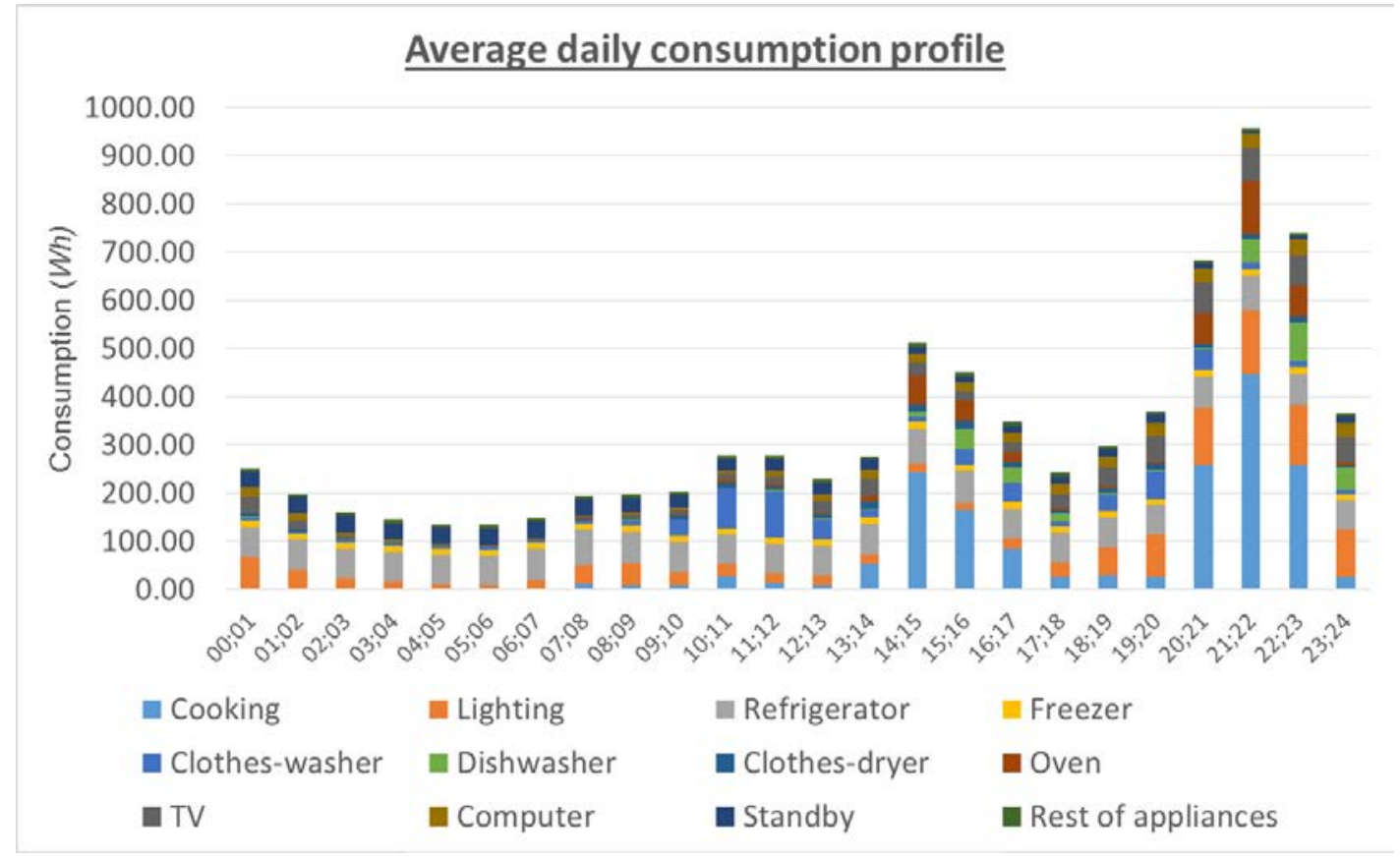


Figure 1: Average daily consumption profile of a Spanish dwelling.

Taking all the above into account, the demands which have been used for the present study (shown in Table 1) are as representative as possible of the current Spanish building sector.

\subsection{Operating protocol}

The system which has been designed for this study has the following characteristics:

- $\quad$ The electricity will be produced by Internal Combustion Engines of $5.5 \mathrm{kWe}$ running on Natural Gas and working in parallel, whose number depends on the total electricity demand for that time-step. To prevent engines from working under their minimum power (thus with a high fuel consumption), the electricity will in those situations be obtained from the grid instead. Consequently, the system will not be isolated.

- A set of 14 photovoltaic panels will produce part of the electricity.

- The heat produced by the engines in the electricity generation process will be used to reduce the energy required by the heating boiler. The DHW system will not be assisted by the recovered energy of the engines.

- A set of 12 solar thermal collectors will reduce the energy required for DHW production.

- The cooling system will be based on air-cooled liquid chillers which run on electricity.

- We will not consider in this study the possibility of selling the electricity surplus of the photovoltaic production to the grid since the vast majority of it will be consumed within the building at the same time it is produced. Batteries to store electricity are also out of the scope of the current study.

\subsection{Equipment sizing}

The sizing of the different elements was carried out by considering many aspects. For example, for the air-cooled chillers the peak loads were taken into account as well as the variations on the performance due to ambient temperature and partial load factors. The auxiliary heating boilers were designed depending on the maximum loads (to cover at least $90 \%$ of the heating hours), which are different for each location.

Another significant example is the sizing of the photovoltaic field considering the maximum and minimum voltage of the panels due to ambient temperature variations, with the purpose of optimising the number of panels. The tilt angle of the PV panels was also chosen depending on the location (equal to the latitude minus $10^{\circ}$ ), so as to maximise the electricity output of the PV array. On the other hand, the tilt angle of the solar thermal collectors is equal to the latitude of the location, which is the optimal value when the system is going to be used throughout the year.

\section{Description of the simulated cases}

The study was carried out considering different configurations of the previously mentioned system including or not all the elements, in order to analyse their impact on energy savings and the costs inferred from the necessary equipment.

The system has been designed with the help of the software TRNSYS 17, which allows making easy alterations of any item included, thus making easier the task of changing parameters, connections and configurations. 
Since changing most parameters of the equipment would not affect the overall calculations in a noticeable way, we have simulated situations in which changes are more influencing and whose results are interesting from an energetic and economical point of view.

The configurations which have been studied are the following:

-Conventional case: in this situation we simulate the installation assuming that all the necessary electricity will be obtained from the grid. Heating and DHW will be provided by boilers running on natural gas.

-Micro-CHP engines: the engines will produce most of the required electricity and the thermal energy they produce will reduce the load of the auxiliary space heating boiler.

-Micro-CHP engines + photovoltaic panels: same previous scenario, including a set of 14 photovoltaic panels which will produce part of the necessary electricity.

-Micro-CHP engines + solar thermal collectors: the engines will be used, and also an array of 12 solar thermal panels which will reduce the load of the auxiliary DHW boiler.

-Micro-CHP engines + photovoltaic panels + solar thermal collectors: all the previously mentioned proposals will be considered at the same time.

\section{TRNSYS implementation}

In this section it is going to be explained the way the system was implemented in order to do all the simulations.

\subsection{Electric subsystem}

First of all, the electric part of the system was designed. It consists of the following elements (for the most complete configuration):

-Air-cooled chillers: a combination of TRNSYS types was used to take into account the performance variations due to ambient temperature fluctuations and partial load factors. Types 42 and 43 were used. A Data Reader (Type 9) indicates the cooling demand.

-Photovoltaic panels: Type 94 was chosen. Technical data provided by the manufacturer was used. The panels are connected to the element which contains the climatic data.

-Inverter: we used Type 175.

-Balance tool: A calculator element was included, which is capable of obtaining for each timestep the balance between the necessary electricity for the building, the one needed by the aircooled water chillers, pump consumptions and the electricity produced by the PV array. After doing so, information is sent to the natural gas engines to indicate the amount of energy they need to produce and how many need to be working in parallel (with the considerations mentioned in the section 2.4).

-Micro-CHP engines: After discussing several possibilities, it was decided to use the TRNSYS type 120 due to its reliability and wide-ranging implementation. This type is initially designed to simulate a diesel engine, but it also allows switching the type of fuel to natural gas. Once this type is told how much electricity it needs to produce, it gives output data of fuel consumption, fuel efficiency, electric efficiency and the waste heat produced, which will later be used to reduce the load of the space heating boiler. 


\subsection{Thermal subsystem}

The thermal part of the installation is responsible for satisfying the DHW and heating needs.

\subsubsection{DHW subsystem}

It consists of the following elements:

-Solar thermal collectors: Its implementation is very similar to that of the photovoltaic panels. Type 73 was used.

- Heat exchanger: It is included so as to separate the primary and secondary circuits of the solar thermal system. A constant efficiency of 0.7 has been considered.

-Hot water storage tank: Type 4 has been used, without any auxiliary heating elements. The total height is divided into six nodes.

-Controller and pumps: two pumps are necessary for each side of the heat exchanger. They will be activated with a control signal which depends on the collectors' output temperature and that from the tank to the collectors.

-Auxiliary DHW heating boiler: We have used Type 6, which corresponds to a boiler of a specified maximum capacity, capable of maintaining a certain output temperature $\left(60^{\circ} \mathrm{C}\right.$ in our case). An efficiency of $92 \%$ is assumed.

-Other elements: Data readers (Type 9) are necessary to supply the data of network water temperature and the profile of hot water consumption (obtained after calculations from Spanish standards). In addition, a mixer and a diverter (Type 11) are used.

\subsubsection{Heating subsystem}

-Recovery of waste heat from the natural gas engines: one of the main purposes of this study is to simulate a micro-CHP system. We are going to assume that $61 \%$ of the waste heat of the engines is potentially recoverable (data consulted in the manufacturer's datasheet). A new tool has been designed, which acts as a heat exchanger in order to calculate which part of the wasted heat is going to be supplied to the heating storage tank.

-Hot water storage tank: the same type as the one for DHW was used.

-Auxiliary space heating boiler: the same type as the one for DHW was used, although with a different maximum capacity (which depends on the climatic zone). The output temperature is set to $80^{\circ} \mathrm{C}$. We suppose a boiler efficiency of $92 \%$.

-Controller and pumps: same as for DHW, but pumps 3 and 4 will be activated only during the winter months when there is heating demand on the building. The temperature difference in the radiators between water forward and water return is calculated through a calculator depending on the demand of each time-step. 


\subsection{Variable optimization}

\subsubsection{Tank volumes}

Once the designs were correctly implemented on TRNSYS, we had the potential to use an optimization tool which enabled us to find the optimum values of certain variables not easily dimensioned, in order to minimise a cost function. In particular, dimensioning the heating tank was a troublesome task due to the abundance of dubious information on this subject.

The tool used is called TRNOPT [48], an interface written to couple TRNSYS with the GENOPT ${ }^{\circledast}$ optimization engine [49] produced by the Lawrence Berkeley National Laboratory (LBNL).

Optimum values for the DHW and heating tanks were pursued so as to minimise the total primary energy consumption of the building in all the climatic zones. The results showed that $2 \mathrm{~m}^{3}$ for the DHW tank was the most favourable solution. There were variations in the obtained values of each case, but very small (less than $1 \%$ ) in comparison with the total consumption of the whole installation. As for the heating tank, the variations were very subtle, so a tank volume of $4 \mathrm{~m}^{3}$. was chosen.

\subsubsection{Number of engines}

At first, the idea was to supply the necessary electricity for the building through several natural gas engines working in parallel. Our first approach consisted on using four engines. However, after obtaining the results we observed that the number of hours that each engine worked was very different. Furthermore, more engines did not necessarily mean less heating consumption, as a result of the lack of simultaneity between when the third and fourth engines work (mainly in summer because of the chiller's electricity needs) and the heating demand. Due to that, the economic feasibility of this option was not suitable, since the third and fourth engines worked for a short period of time in all the designs considered and the investment costs were substantial. The main conclusion that can be drawn from these results, is that the engines must operate for as long as possible in order to improve the economic profitability of their implementation.

One example was the following:

\begin{tabular}{|l|l|}
\hline Number of engines & Working hours \\
\hline $\mathbf{1}$ & 6398 \\
\hline $\mathbf{2}$ & 1714 \\
\hline $\mathbf{3}$ & 465 \\
\hline $\mathbf{4}$ & 90 \\
\hline
\end{tabular}

Table 3: Yearly working hours of each micro-CHP engine considered.

As a result, we assumed a number of two engines working in parallel for each design and climatic zone. The main reason is that although the number of hours that the two engines work at the same time is not particularly high, having two engines also adds security of energy supply in case of fault or maintenance.

\subsubsection{Surplus electricity}


After analysing preliminary results, we could observe that the proposed photovoltaic subsystem only produced surplus electricity a few hours per year, just as could be foreseen. Thus, the sale of electricity is not considered given all the inconveniences involved, as well as the need of the inclusion of batteries.

\subsection{TRNSYS system diagram}

The resulting diagram of the installation differs depending on which of the five designs is being analysed. As an example, the TRNSYS outline of the most complete design is the following:

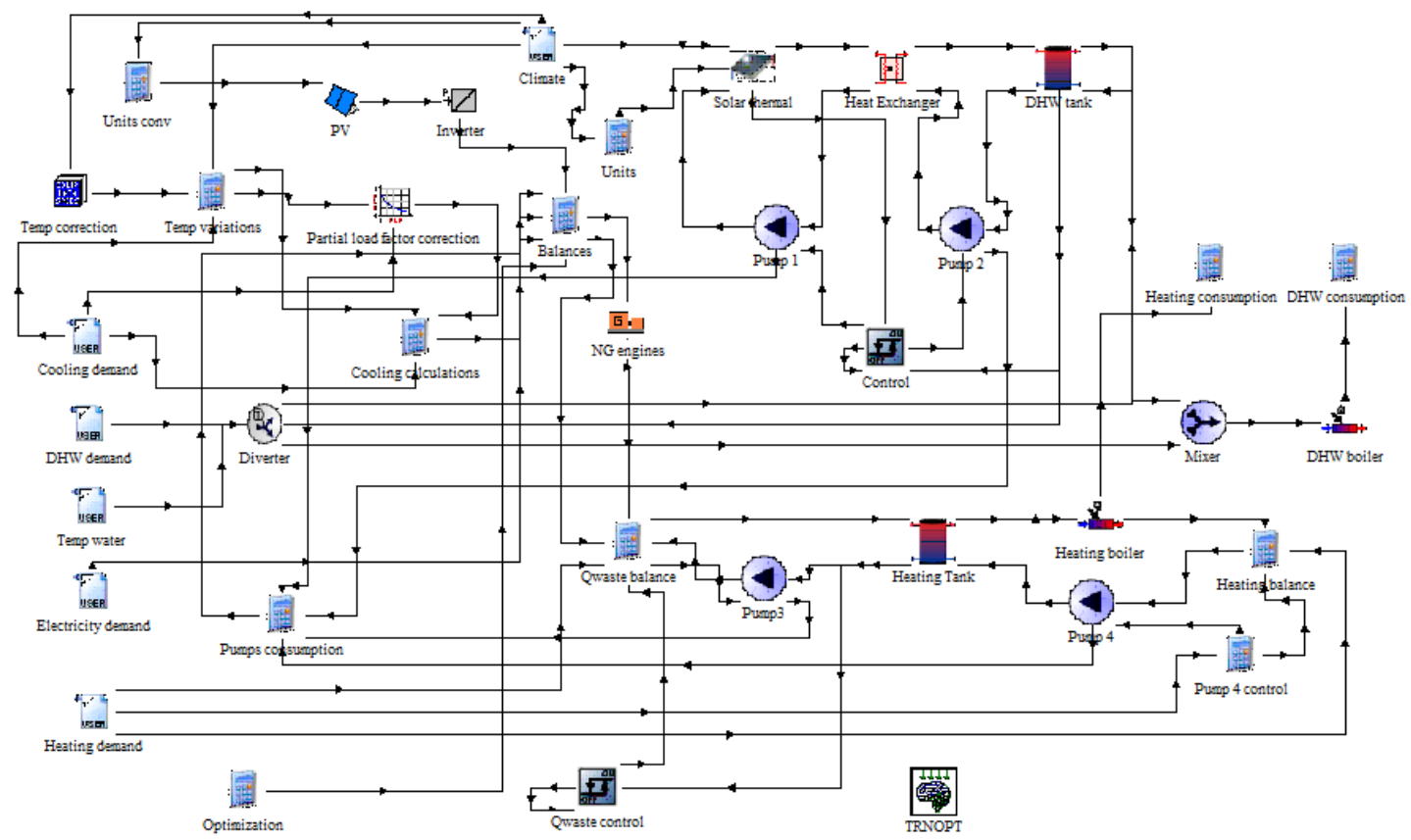

Figure 2: Interconnections between Types for the whole system considered in this paper.

\section{Analysis of results}

\subsection{Calculations}

Once all the simulations were carried out, it was possible to obtain the annual aggregated consumptions of the main elements of the plant for each of the five considered designs, and each climatic zone. The most important are the following:

-Annual heating consumption.

-Annual Domestic Hot Water Consumption.

-Annual consumption of the engines.

-Annual electricity consumption (cooling, pumps and building electricity needs).

Consequently, we were able to perform all the necessary calculations in order to know the fuel consumption for each element. In addition, we were in a position to ultimately calculate the primary energy consumptions, total costs of operation and total $\mathrm{CO}_{2}$ emissions. 
The primary energy and emission factors (obtained from [50]) and the energy costs considered are the following:

-Natural Gas primary energy factor [kWh/kWh]: 1.07

-Grid electricity primary energy factor [kWh/kWh]: 2.35

-Natural gas emission factor: $0.204 \mathrm{kgCO}_{2} / \mathrm{kWh}$

-Grid electricity emission factor: $0.649 \mathrm{kgCO}_{2} / \mathrm{kWh}$

-Natural Gas cost: $0.068 € / k W h$

-Electricity cost: $0.209 € / \mathrm{kWh}$

One of the purposes of the study was to determine the Life Cycle Cost (LCC) for each case. A time span of 30 years was considered, which includes the capital investment, operation, replacement, and maintenance costs. The values for the LCC were obtained with the following equation:

$$
L C C=\text { Initial }_{\text {investment }}+\text { Costs }_{\text {replacement }}+\left(\text { Costs }_{\text {operation }}+\text { Costs }_{\text {maintenance }}\right) \cdot \sum_{t=1}^{30} \frac{1}{(1+r)^{t}}
$$

Where " $\mathrm{t}$ " is the year, and " $\mathrm{r}$ " is the inflation rate (considered as $3 \%$ ).

The succeeding tables sum up the accomplished results:

\begin{tabular}{|l|l|l|l|l|l|}
\hline $\begin{array}{l}\text { PRIMARY ENERGY CONSUMPTION } \\
{\left[\mathrm{kWh} / \mathrm{m}^{2}\right]}\end{array}$ & A3 & B4 & C2 & D3 & E1 \\
\hline Conventional case & 92.95 & 106.14 & 102.93 & 122.44 & 125.73 \\
\hline Micro-CHP engines & 110.31 & 121.00 & 110.01 & 125.57 & 123.58 \\
\hline Micro-CHP engines + $\mathrm{pv}$ & 94.75 & 106.28 & 98.03 & 114.44 & 113.40 \\
\hline Micro-CHP engines +solar thermal & 99.60 & 110.03 & 101.01 & 116.17 & 114.38 \\
\hline Micro-CHP engines +pv + solar thermal & 83.80 & 94.96 & 88.74 & 104.80 & 104.84 \\
\hline
\end{tabular}

Table 4: Primary energy consumption for each configuration and climatic zone considered.

\begin{tabular}{|l|l|l|l|l|l|}
\hline EMISSIONS $\left[\mathrm{kgCO}_{2} / \mathrm{m}^{2}\right]$ & A3 & B4 & $\mathrm{C} 2$ & D3 & E1 \\
\hline Conventional case & 23.91 & 27.17 & 25.37 & 29.73 & 29.44 \\
\hline Micro-CHP engines & 22.10 & 24.75 & 21.77 & 25.17 & 24.23 \\
\hline Micro-CHP engines +pv & 19.40 & 22.16 & 19.75 & 23.26 & 22.58 \\
\hline Micro-CHP engines +solar thermal & 20.02 & 22.62 & 20.02 & 23.34 & 22.44 \\
\hline Micro-CHP engines +pv + solar thermal & 17.32 & 20.01 & 17.99 & 21.43 & 20.95 \\
\hline
\end{tabular}

Table 5: Emissions $\left[\mathrm{kgCO}_{2} / \mathrm{m}^{2}\right]$ for each configuration and climatic zone considered. 


\begin{tabular}{|l|l|l|l|l|l|}
\hline LCC $\left[€ / \mathrm{m}^{2}\right]$ & A3 & B4 & C2 & D3 & E1 \\
\hline Conventional case & 162.79 & 186.74 & 172.69 & 202.65 & 199.21 \\
\hline Micro-CHP engines & 213.45 & 233.50 & 211.48 & 235.33 & 227.44 \\
\hline Micro-CHP engines +pv & 215.98 & 236.77 & 218.47 & 243.07 & 236.80 \\
\hline Micro-CHP engines +solar thermal & 225.85 & 245.55 & 226.04 & 249.40 & 241.74 \\
\hline Micro-CHP engines +pv + solar thermal & 228.34 & 248.68 & 232.89 & 257.05 & 252.08 \\
\hline
\end{tabular}

Table 6: Life Cycle Cost $\left[€ / \mathrm{m}^{2}\right]$ for each configuration and climatic zone considered.

\subsection{Comparison between design alternatives}

For the sake of clarity we have created three sets of graphs that allow the comparison between the different designs and climatic zones.

As will become clear below, the lowest Life Cycle Cost is always the one of the conventional design. Conversely, it is the design with higher emissions, and its primary energy consumption is never the lowest between those examined. The results will be further clarified in sections 5.3, 5.4 and 5.5.

In order to facilitate the comprehension of the charts, one of them is going to be explained in more detail:

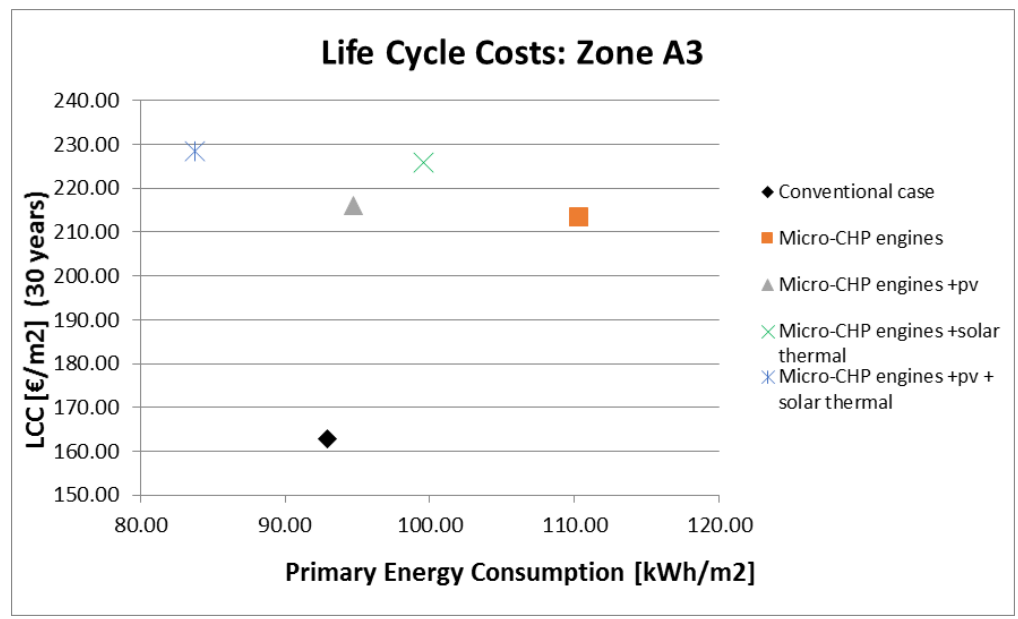

Figure 3: Life Cycle Cost $\left[€ / \mathrm{m}^{2}\right]$ vs Primary Energy Consumption $\left[\mathrm{kWh} / \mathrm{m}^{2}\right]$ of the climatic zone A3

In this case, we can safely say that the conventional case has the lowest Life Cycle Cost, whilst the most complete design (which includes engines, PV and solar thermal panels) is the one with the highest, not far from the other configurations. However, the primary energy consumption of the complete design is lower than that of the conventional case, which is the second lowest. In this particular case the design with only micro-CHP engines is the one with a higher primary energy consumption. 
The following figure shows the whole set of graphs:
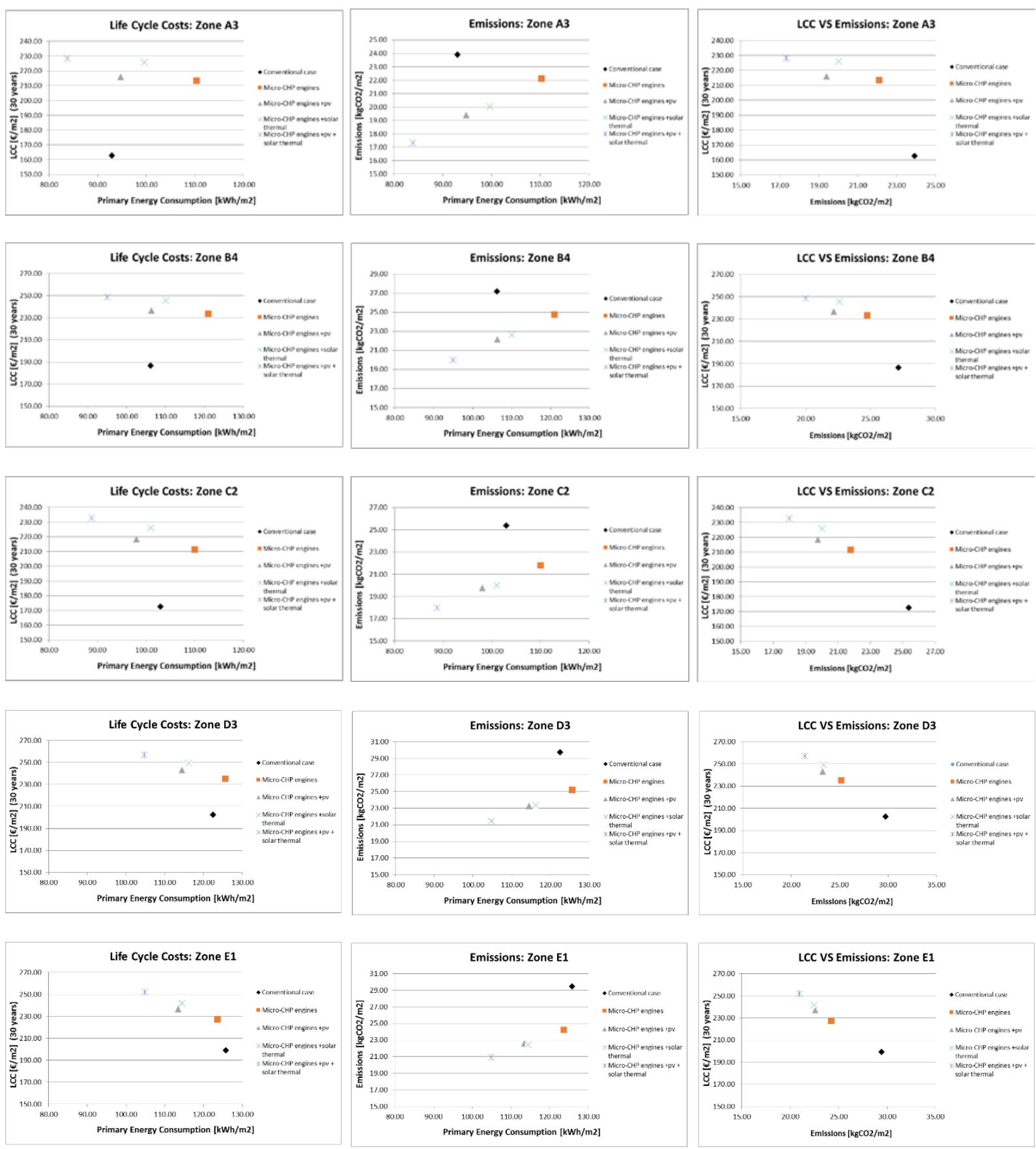

Figure 4: Life Cycle Cost $\left[€ / \mathrm{m}^{2}\right]$ vs Primary Energy Consumption $\left[\mathrm{kWh} / \mathrm{m}^{2}\right]$, Emissions $\left[\mathrm{kgCO}_{2} / \mathrm{m}^{2}\right]$ vs Primary Energy Consumption $\left[\mathrm{kWh} / \mathrm{m}^{2}\right.$ ] and Life Cycle Cost $\left[€ / \mathrm{m}^{2}\right]$ (30 years) vs emissions for each of the five climatic zones considered. 


\subsection{Primary energy savings}

As is apparent, these results show that the primary energy consumption of the conventional design is never the lowest among all those considered. The most complete design has a lower consumption in zones A3 and B4, and in the others even other designs are better than the conventional case. The colder the climate, the higher the reduction of heating consumption thanks to the engines. However, the results may vary since hotter climates need more electricity for the chillers in the summer. All in all, the balance of energy between that produced by the engines (consuming natural gas) and the electricity obtained from the grid can cause these discordances between climates.

\subsection{Life Cycle Cost}

On the other hand, the LCC of the conventional design is the lowest in all the climatic zones. Anyhow, the differences vary between different climatic zones. In colder climates such as E1 or D3, the differences are lower between the conventional case and the rest of designs. The main reason is that heating consumptions are much more reduced thanks to the waste heat of the engines, because of the higher heating demands in comparison with that of hotter climates.

The higher LCC in every design is mostly due to the considerable influence of the initial investment, whose energy savings do not compensate the additional costs. Furthermore, the maintenance costs are noteworthy.

One of the conclusions drawn from this which goes hand in hand with many other studies, is that microCHP engines are still being investigated and integrated within buildings but their technology is not yet economically feasible in certain disciplines. However, in the near future a full scale production might contribute to diminishing the investment costs, which could change the landscape of energy dramatically.

\subsection{Emissions}

In contrast with the previous results, it can be seen that the conventional design is the one with higher emissions. That is mostly due to the fact that more electricity from the grid is used, which entails a higher emission factor than other energy carriers. Among the other designs, the one with all the elements (engines, photovoltaic and solar thermal collectors) has the lower emissions in all the climatic zones.

This result reinforces the theory that profitability and emissions do not often go together, since improving one may penalise the other. As said before, the economy of scale might reverse this situation in the future.

\subsection{Operating hours of the engines}

Another significant outcome of the study is the possibility to observe the number of hours that each engine works in each design and climatic zone. According to our model, the second engine will be started only if more energy than that which one engine can provide is needed. Therefore, throughout the year the first engine will operate more frequently than the second.

The results are the following: 


\begin{tabular}{|c|c|c|c|c|c|c|}
\hline Design & Engines functioning & $\begin{array}{l}\text { A3 } \\
{[\mathrm{h}]}\end{array}$ & $\begin{array}{l}\text { B4 } \\
\text { [h] }\end{array}$ & $\begin{array}{l}\text { C2 } \\
{[\mathrm{h}]}\end{array}$ & $\begin{array}{l}\text { D3 } \\
\text { [h] }\end{array}$ & $\begin{array}{l}\text { E1 } \\
\text { [h] }\end{array}$ \\
\hline \multirow{3}{*}{ Conventional case } & No engines working & 8760 & 8760 & 8760 & 8760 & 8760 \\
\hline & 1st engine working & 0 & 0 & 0 & 0 & 0 \\
\hline & $\begin{array}{l}2 \text { engines working in } \\
\text { parallel }\end{array}$ & 0 & 0 & 0 & 0 & 0 \\
\hline \multirow{3}{*}{ Micro-CHP engines } & No engines working & 2161 & 2149 & 2107 & 2095 & 2088 \\
\hline & 1st engine working & 6599 & 6611 & 6653 & 6665 & 6672 \\
\hline & $\begin{array}{l}2 \text { engines working in } \\
\text { parallel }\end{array}$ & 1956 & 2041 & 1824 & 1963 & 1694 \\
\hline \multirow{3}{*}{ Micro-CHP engines +PV } & No engines working & 4174 & 4077 & 3876 & 3852 & 3826 \\
\hline & 1st engine working & 4586 & 4683 & 4884 & 4908 & 4934 \\
\hline & $\begin{array}{l}2 \text { engines working in } \\
\text { parallel }\end{array}$ & 1545 & 1650 & 1442 & 1606 & 1327 \\
\hline \multirow{3}{*}{$\begin{array}{l}\text { Micro-CHP engines +solar } \\
\text { thermal }\end{array}$} & No engines working & 2035 & 2010 & 2001 & 1986 & 1981 \\
\hline & 1st engine working & 6725 & 6750 & 6759 & 6774 & 6779 \\
\hline & $\begin{array}{l}2 \text { engines working in } \\
\text { parallel }\end{array}$ & 1960 & 2044 & 1844 & 1979 & 1740 \\
\hline \multirow{3}{*}{$\begin{array}{l}\text { Micro-CHP engines +PV + } \\
\text { solar thermal }\end{array}$} & No engines working & 4124 & 4024 & 3829 & 3811 & 3766 \\
\hline & 1st engine working & 4636 & 4736 & 4931 & 4949 & 4994 \\
\hline & $\begin{array}{l}2 \text { engines working in } \\
\text { parallel }\end{array}$ & 1548 & 1654 & 1450 & 1609 & 1332 \\
\hline
\end{tabular}

Table 7: Disaggregation of the number of hours that each engine works in each design and climatic zone.

As we can see, in every case there are many hours in which no engine is operating. The reason for that is that the electricity needs are below the minimum power of an engine ( $40 \%$ of the rated power).

The first engine operates many hours per year, in contrast with the second one which does so less frequently. However, as we said previously the second engine also serves as backup, and thus it is convenient in every design.

\subsection{Optimum design for each climatic zone}

Relying in all the obtained data, we can observe that the optimum design for each climatic zone depends on the chosen criteria, since LCC, primary energy consumption and emissions are not analogous. The summary showing the order of preference for each case study is the ensuing: 


\begin{tabular}{|c|c|c|c|c|c|c|}
\hline Design & CRITERIA & A3 & B4 & $\mathrm{C2}$ & D3 & E1 \\
\hline \multirow{3}{*}{ Conventional case } & LCC & 1 & 1 & 1 & 1 & 1 \\
\hline & $\begin{array}{l}\text { PRIMARY } \\
\text { ENERGY }\end{array}$ & 2 & 2 & 4 & 4 & 5 \\
\hline & EMISSIONS & 5 & 5 & 5 & 5 & 5 \\
\hline \multirow{3}{*}{ Micro-CHP engines } & LCC & 2 & 2 & 2 & 2 & 2 \\
\hline & $\begin{array}{l}\text { PRIMARY } \\
\text { ENERGY }\end{array}$ & 5 & 5 & 5 & 5 & 4 \\
\hline & EMISSIONS & 4 & 4 & 4 & 4 & 4 \\
\hline \multirow{3}{*}{ Micro-CHP engines +PV } & LCC & 3 & 3 & 3 & 3 & 3 \\
\hline & $\begin{array}{l}\text { PRIMARY } \\
\text { ENERGY }\end{array}$ & 3 & 3 & 2 & 2 & 2 \\
\hline & EMISSIONS & 2 & 2 & 2 & 2 & 3 \\
\hline \multirow{3}{*}{$\begin{array}{l}\text { Micro-CHP engines +solar } \\
\text { thermal }\end{array}$} & LCC & 4 & 4 & 4 & 4 & 4 \\
\hline & $\begin{array}{l}\text { PRIMARY } \\
\text { ENERGY }\end{array}$ & 4 & 4 & 3 & 3 & 3 \\
\hline & EMISSIONS & 3 & 3 & 3 & 3 & 2 \\
\hline \multirow{3}{*}{$\begin{array}{l}\text { Micro-CHP engines +PV + } \\
\text { solar thermal }\end{array}$} & LCC & 5 & 5 & 5 & 5 & 5 \\
\hline & $\begin{array}{l}\text { PRIMARY } \\
\text { ENERGY }\end{array}$ & 1 & 1 & 1 & 1 & 1 \\
\hline & EMISSIONS & 1 & 1 & 1 & 1 & 1 \\
\hline
\end{tabular}

Table 8: Order of preference of each design for each climatic zone depending on the chosen criteria, where 1 is the best solution and 5 the worst.

\subsection{Sensitivity analysis of costs}

Nowadays, the costs of renewable technologies are changing continuously and significant reductions can still be expected, which means that the analysed configurations might be profitable in the future under certain circumstances.

\subsubsection{Investment costs of solar panels}

A sensitivity analysis depending on the investment costs of the solar panels was carried out, in order to check what the situation would be if their costs were to be reduced. However, the results were conclusive and showed that the relative weight of the solar panels was very low compared to that of the whole system (mainly the price of the engines), which implied that reducing their cost would not make a noticeable difference in our case studies, as can be seen in the following example of the climatic zone B4 if the solar panel prices were to be reduced: 


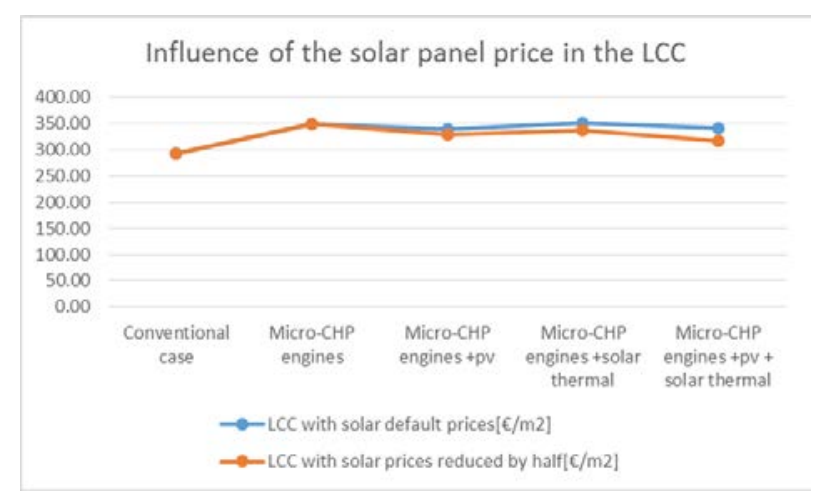

Figure 5: influence of the solar panel price in the LCC of the climatic zone B4

\subsubsection{Sensitivity analysis of energy prices}

Alternatively, the influence of the operation costs has been analysed taking into account different price scenarios in which the electricity and natural gas prices are increased.

The considered scenarios are the following:

\begin{tabular}{|c|c|c|}
\hline PRICE SCENARIO & EL. PRICE [€/kWh] & NG PRICE [€/kWh] \\
\hline S1 & 0.209 & 0.068 \\
S2 & 0.33 & 0.068 \\
S3 & 0.40 & 0.068 \\
S4 & 0.33 & 0.12 \\
S5 & 0.33 & 0.15 \\
S6 & 0.40 & 0.12 \\
S7 & 0.40 & 0.15 \\
\hline
\end{tabular}

Table 9: Price Scenarios

A sensitivity analysis was performed with these price scenarios in every climatic zone. Since the results among them were very similar, only the outcomes of the climatic zone E1 are going to be illustrated:

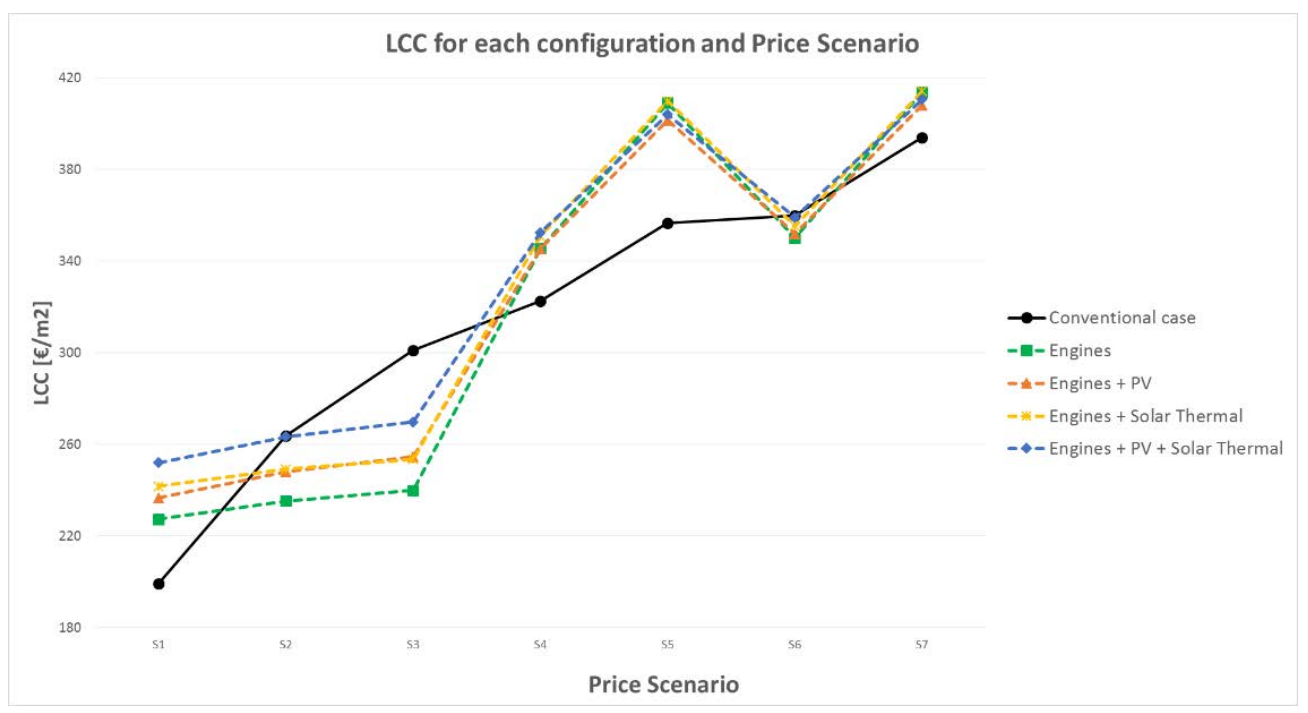

Figure 6: Life Cycle Cost for each configuration and Price Scenario of the climatic zone E1 
On the basis of the obtained results, we can see that the first scenario (the one used for the calculations of the previous sections) benefits the conventional design. Meanwhile, the second scenario implies an increase of the electricity cost without modifying the natural gas cost. It basically results in a worsening of the conventional case compared to the others, making it the one with the highest LCC (although very close to the most complete configuration).

Under the third scenario the same pattern is repeated: the LCC of the conventional case is notoriously increased, whilst the LCC of the other designs is only slightly affected. The main reason is that the conventional design uses a lot of electricity from the grid, in contrast to the others which produce most of the electricity through the CHP engines or PV panels.

The rest of the scenarios suppose an increase in both electricity and natural gas costs; various situations that may be encountered in practice. The general conclusion that may be drawn from this data is that the more the electricity costs are increased, the more the profitability of the innovative designs compared to the conventional case. In contrast, an increase in the natural gas prices undermines the profitability of the innovative designs, since their natural gas consumption is higher than that of the conventional case.

\section{Conclusions}

This paper has provided an overview of the role of distributed generation and cogeneration in particular within the energy sector. Several possibilities of design have been shown integrating natural gas engines together with renewable resources, supplying the energy for a very representative building in Spain.

The present study has obtained evidence on the overall behaviour of such systems. Calculations have been developed in order to obtain a comparison depending on the chosen criteria (Life Cycle Cost, emissions or primary energy consumption) for the considered designs and climatic zones. A table showing the order of preference for each case study depending on those criteria is presented so as to determine the ideal solutions. The importance of the engine work hours has also been highlighted, as well as that of the climate when choosing the optimal design.

According to the results obtained, as far as the LCC is concerned the conventional case is the best one in all cases. Therefore, more work remains to be done, mostly by the manufacturers regarding the cost of the engines through technological innovations allowed by economies of scale, and the removal of administrative barriers by the governments themselves. This would make the projects more profitable, and attract new investors. On the other hand, as has been seen, if properly designed hybrid systems suppose a decrease in energy consumption and emissions, reaffirming their usefulness and the important role they can play in the near future. 


\section{$\underline{\text { References }}$}

[1] Amir H. Nosrat, Lukas G. Swan, Joshua M. Pearce. Simulations of greenhouse gas emission reductions from low-cost hybrid solar photovoltaic and cogeneration systems for new communities. Sustainable Energy Technologies and Assessments 8 (2014) 34-41.

[2] G. Conroy, A. Duffy, L.M. Ayompe. Economic, energy and GHG emissions performance evaluation of a WhisperGen Mk IV Stirling engine I -CHP unit in a domestic dwelling. Energy Conversion and Management 81 (2014) 465-474.

[3] J. Milewski, Ł. Szabłowski, J Kuta. Control strategy for an Internal Combustion engine fuelled by Natural Gas operating in Distributed Generation. International Conference on Advances in Energy Engineering. Energy Procedia 14 (2012) 1478 - 1483.

[4] Williams, J. Strakey, S. C. Singhal. U.S. distributed generation fuel cell program. Journal of Power Sources 131 (2004) 79--85.

[5] WT. Budzianowski. Negative net $\mathrm{CO} 2$ emissions from oxy-decarbonization of biogas to h2. International Journal of Chemical Reactor Engineering 8 (2010) A156.

[6] V. Kuhn, J. Klemeš, I. Bulatov. MicroCHP: overview of selected technologies, products and field test results. Applied Thermal Engineering (2008); 28(16):2039-48.

[7] E. Entchev, L. Yang, F. Szadkowski, M. Armstrong, M. Swinton. Application of hybrid microcogeneration system-Thermal and power energy solutions for Canadian residences. Energy and Buildings 60 (2013) 345-354.

[8] M.A. Ehyaei, P. Ahmadi, F. Atabi, M.R. Heibati, M. Khorshidvand. Feasibility study of applying internal combustion engines in residential buildings by exergy, economic and environmental analysis. Energy and Buildings 55 (2012) 405-413.

[9] X.L. Zhao , L. Fu, S.G. Zhang, Y. Jiang, H. Li. Performance improvement of a 70 kWe natural gas combined heat and power (CHP) system. Energy 35 (2010) 1848-1853.

[10] A. H. Nosrat , L. G. Swan, J. M. Pearce. Improved performance of hybrid photovoltaictrigeneration systems over photovoltaic-cogen systems including effects of battery storage. Energy 49 (2013) 366-374. 
[11] J. Dekker, M. Nthontho, S. Chowdhury, S.P. Chowdhury. Economic analysis of PV/diesel hybrid power systems in different climatic zones of South Africa. Electrical Power and Energy Systems 40 (2012) 104-112.

[12] J Kaldellis, D Zafirakis, K Kavadias, E Kondili. Optimum PV-diesel hybrid systems for remote consumers of the Greek territory. Applied Energy 97 (2012) 61-67.

[13] A. Kaabeche, R. Ibtiouen. Techno-economic optimization of hybrid photovoltaic/wind/diesel/battery generation in a stand-alone power system. Solar Energy 103 (2014) 171-182.

[14] H. Tazvinga, X. Xia, J. Zhang. Minimum cost solution of photovoltaic-diesel-battery hybrid power systems for remote consumers. Solar Energy 96 (2013) 292-299.

[15] N. Agarwal, A. Kumar, Varun. Optimization of grid independent hybrid PV-diesel-battery system for power generation in remote villages of Uttar Pradesh, India. Energy for Sustainable Development 17 (2013) 210-219.

[16] D. Yamegueu, Y. Azoumah, X. Py, N. Zongo. Experimental study of electricity generation by Solar PV/diesel hybrid systems without battery storage for off-grid areas. Renewable Energy 36 (2011) $1780 \mathrm{e} 1787$.

[17] M. Bianchi, A. De Pascale, F. Melino. Performance analysis of an integrated CHP system with thermal and Electric Energy Storage for residential application. Applied Energy 112 (2013) 928-938.

[18] A.Campos Celador, M. Odriozola, J.M. Sala. Implications of the modelling of stratified hot water storage tanks in the simulation of CHP plants. Energy Conversion and Management 52 (2011) 3018-3026.

[19] A. Ghasemi, A. Asrari, M. Zarif, S. Abdelwahed. Techno-economic analysis of stand-alone hybrid photovoltaic-diesel-battery systems for rural electrification in eastern part of Iran-A step toward sustainable rural development. Renewable and Sustainable Energy Reviews 28 (2013) 456-462.

[20] J. L. Bernal-Agustiín, R. Dufo-López. Simulation and optimization of stand-alone hybrid renewable energy systems. Renewable and Sustainable Energy Reviews 13 (2009) 2111-2118.

[21] A. Brandoni, M. Renzi , F. Caresana , F. Polonara. Simulation of hybrid renewable microgeneration systems for variable electricity prices. Applied Thermal Engineering 71 (2014) 667-676.

[22] S. Farhad, F. Hamdullahpur, Y. Yoo. Performance evaluation of different configurations of biogas-fuelled SOFC micro-CHP systems for residential applications. International journal of hydrogen energy 35 (2010) 3758-3768.

[23] E. S. Barbieri, F. Melino, M. Morini. Influence of the thermal energy storage on the profitability of micro-CHP systems for residential building applications. Applied Energy 97 (2012) 714-722. 
[24] H Lee, J Bush, Y Hwang, R Radermacher. Modeling of micro-CHP (combined heat and power) unit and evaluation of system performance in building application in United States. Energy 58 (2013) 364e375.

[25] T. Ma, H. Yang, L. Lu. A feasibility study of a stand-alone hybrid solar-wind-battery system for a remote island. Applied Energy 121 (2014) 149-158.

[26] S. Cao, A. Mohamed, A. Hasan, K. Sirén. Energy matching analysis of on-site microcogeneration for a single-family house with thermal and electrical tracking strategies. Energy and Buildings 68 (2014) 351-363.

[27] M. P. McHenry. A technical, economic, and greenhouse gas emission analysis of a homestead-scale grid-connected and stand-alone photovoltaic and diesel systems, against electricity network extension. Renewable Energy 38 (2012) 126e135.

[28] P.J. Mago, L.M. Chamra. Analysis and optimization of CCHP systems based on energy, economical, and environmental considerations. Energy and Buildings 41 (2009) 1099-1106.

[29] M. Houwing, A.N. Ajah, P.W. Heijnen, I. Bouwmans, P.M. Herder. Uncertainties in the design and operation of distributed energy resources: the case of micro- CHP systems. Energy 33 (2008) 1518-1536.

[30] Y. Hamada, K. Takeda, R. Goto, H. Kubota. Hybrid utilization of renewable energy and fuel cells for residential energy systems. Energy and Buildings 43 (2011) 3680-3684.

[31] A. Campos Celador, A. Erkoreka, K. Martin Escudero, J.M. Sala. Feasibility of small-scale gas engine-based residential cogeneration in Spain. Energy Policy 39 (2011) 3813-3821.

[32] S. Obara, S. Watanabe, B. Rengarajan. Operation method study based on the energy balance of an independent microgrid using solar- powered water electrolyzer and an electric heat pump. Energy 36 (2011) 5200-5213.

[33] V. Dorer, R. Weber, A. Weber. Performance assessment of fuel cell micro- cogeneration systems for residential buildings. Energy and Buildings 37 (2005) 1132-1146.

[34] J.L. Wang, J.Y. Wu, C.Y. Zheng. Simulation and evaluation of a CCHP system with exhaust gas deep-recovery and thermoelectric generator. Energy Conversion and Management 86 (2014) 992-1000.

[35] B. Ould. Bilal, V. Sambou, C.M.F Kébé, P. A. Ndiaye, M. Ndongo. Methodology to Size an Optimal Stand-Alone PV/wind/diesel/battery System Minimizing the Levelized cost of Energy and the CO2 Emissions. Energy Procedia 14 (2012) 1636- 1647.

[36] B.V. Mathiesen, H. Lund, D. Connolly, H. Wenzel. Smart Energy Systems for coherent $100 \%$ renewable energy and transport solutions. Applied Energy 145 (2015) 139-154.

[37] D. Sig Chai, J. Z. Wena, J. Nathwani. Simulation of cogeneration within the concept of smart energy networks. Energy Conversion and Management 75 (2013) 453-465. 
[38] H. Lund, A. N. Andersen, Poul Alberg Østergaard, Brian Vad Mathiesen, David Connolly. From electricity smart grids to smart energy systems - A market operation based approach and understanding. Energy 42 (2012) 96-102.

[39] J.M. Salmerón, S. Álvarez, J.L. Molina, A. Ruiz, F.J. Sánchez. Tightening the energy consumptions of buildings depending on their typology and on Climate Severity Indexes. Energy and Buildings 58 (2013) 372-377.

[40] P. Stathopoulos, C.O. Paschereit. Retrofitting micro gas turbines for wet operation. A way to increase operational flexibility in distributed CHP plants. Applied Energy 154 (2015) 438-446.

[41] E. Merkel, R. McKenna, W. Fichtner. Optimisation of the capacity and the dispatch of decentralized micro-CHP systems: A case study for the UK. Applied Energy 140 (2015) 120-134.

[42] R. Luthander, J. Widén, D. Nilsson, J. Palm. Photovoltaic self-consumption in buildings: A review. Applied Energy 142 (2015) 80-94.

[43] J. Wang, Y. Yang, T. Mao, J. Sui, H. Jin. Life cycle assessment (LCA) optimization of solarassisted hybrid CCHP system. Applied Energy 146 (2015) 38-52.

[44] Ministerio de Fomento. Government of Spain. LIDER software. http://www.codigotecnico.org/index.php/es/menu-programa-lider (2009).

[45] Project "EURECO": End-use metering campaign in 400 households of the European Community. Partially funded by Commission of the European Communities (2002).

[46] Project "SPAHOUSEC": Analysis of the Energy Consumption in the Spanish Households. IDAE (2011).

[47] Project "ENCERTICUS": Energy Certification, Technology, Information and Communication for User Benefit. Partially funded by European Regional Development Fund (ERDF) (2015).

[48] Thermal Energy System Specialists (TESS). TRNOPT v17 Installation, Run-Time Instructions, and License Agreement (2010).

[49] M. Wetter, GenOpt: generic optimization program, http://gundog.lbl.gov/GO/ (2011).

[50] Boletines de Coyuntura Energética y Balances Energéticos: Factores de conversión de energía primaria y emisiones de CO2. IDAE, Ministerio de Industria, Turismo y Comercio, Gobierno de España (2010). 